Imidazo-benzo-15-crown-5 ethers bearing arylthienyl and bithienyl moieties as novel fluorescent chemosensors for $\mathrm{Pd}^{2+}$ and $\mathrm{Cu}^{2+}$

Rosa M. F. Batista, Elisabete Oliveira, Susana P. G. Costa, ${ }^{1}$ Carlos Lodeiro and M. Manuela M. Raposo

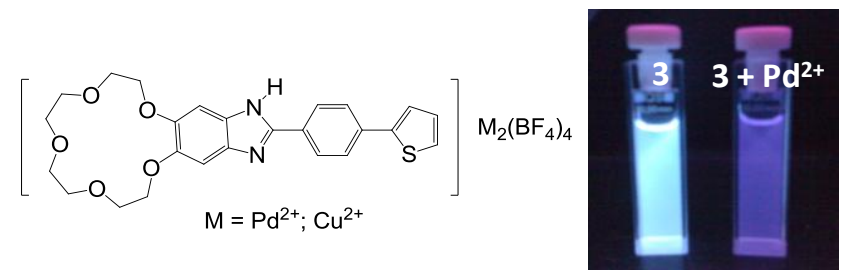




\title{
Imidazo-benzo-15-crown-5 ethers bearing arylthienyl and bithienyl moieties as novel fluorescent chemosensors for $\mathrm{Pd}^{2+}$ and $\mathrm{Cu}^{2+}$
}

\author{
Rosa M. F. Batista, ${ }^{1}$ Elisabete Oliveira, ${ }^{2}$ Susana P. G. Costa, ${ }^{1}$ Carlos Lodeiro ${ }^{2,3 *}$ and M. \\ Manuela M. Raposo ${ }^{1 *}$ \\ ${ }^{1}$ Center of Chemistry, Univeristy of Minho, Campus Gualtar, 4710-057 Braga, Portugal \\ ${ }^{2}$ REQUIMTE, Department of Chemistry, FCT-UNL, 2829-516 Monte de Caparica, Portugal \\ ${ }^{3}$ BIOSCOPE Group, Faculty of Science, Physical-Chemistry Department, Campus Ourense, \\ University of Vigo, 32004, Ourense, Spain. \\ *Corresponding author Tel: + 351253 604381; Fax: + 351253604382 \\ email:mfox@quimica.uminho.pt
}

Dedicated to the Centenary of the Portuguese Chemical Society

\begin{abstract}
Novel fluorescent ionophores bearing imidazo-arylthienyl or imidazo-bithienyl $\pi$ conjugated bridges functionalized with one or two fused benzo-15-crown-5 ethers as receptor units are reported. The sensing ability of the compounds in the presence of metallic cations $\left(\mathrm{Li}^{+}, \mathrm{Na}^{+}, \mathrm{K}^{+}, \mathrm{Ca}^{2+}, \mathrm{Zn}^{2+}, \mathrm{Cu}^{2+}, \mathrm{Ni}^{2+}, \mathrm{Pd}^{2+}\right.$ and $\left.\mathrm{Hg}^{2+}\right)$ and fluoride ion was studied in MeCN/DMSO solutions by absorption and emission spectroscopy. The experimental results indicate that all compounds could act as selective fluorimetric sensors for $\mathrm{Cu}^{2+}$ and $\mathrm{Pd}^{2+}$ and also for the fluoride ion, in the case of the bis-substituted crown ether derivatives.
\end{abstract}

Keywords: Crown ethers, Arylthiophene, Bithiophene, Imidazole, Fluorescent chemosensors, CHEQ effect, $\mathrm{Pd}^{2+}, \mathrm{Cu}^{2+}, \mathrm{F}^{-}$.

\section{Introduction}

The development of artificial receptors for the sensing and recognition of environmentally and biologically important ionic species is currently of great interest. Highly selective anion ${ }^{1}$ or cation $^{2}$ sensing is imperative for many areas, including environmental, biological, clinical, and waste management applications. 
The potential for progress in the development of fluorescent sensors can be explained by the distinct advantages offered by fluorescence detection in terms of sensitivity, selectivity, response time, local observation, etc. Typically, an auxochrome generating the fluorescence signal is combined with an analyte-responsive receptor via a saturated or unsaturated spacer. The sensing properties of such systems depend on the receptor-controlled (chemical) selectivity and the analyte-mediated (spectroscopic) signaling selectivity as well as sensitivity. Suitable fluorescent reporters must efficiently transduce a binding event into a measurable fluorescence signal, thereby taking advantage of the intrinsic selectivity of communication of fluorescence via two experimental parameters, excitation and emission wavelength, and its high sensitivity. ${ }^{1 \mathrm{c}-\mathrm{d}, 3}$

Crown ether derivatives occupy a special position among receptors and are widely used in the design of new chemosensors based on their unique ability to coordinate the cations of alkaline metals, their fairly high selectivity and accessibility. In addition to alkaline metals, crown ethers are also effective complexing reagents for the cations of alkaline-earth metal ions and transition metal ions. ${ }^{4}$ On the other hand, hydrogen-bond donors such as pyrrole/calixpyrrole, (thio)urea, dipyrrolylquinoxalines, indolocarbazoles, and (benzo)imidazole usually act as anion binding sites and the acidity of the NH proton of the imidazole can be tuned by changing the electronic properties of the imidazole substituents. ${ }^{5}$ Recently, 2,4,5triaryl(heteroaryl)-imidazole-based chromophores have received increasing attention due to their interesting optical properties. For example, one of the most interesting applications are as fluorescent chemosensors. ${ }^{6 a-c}$ The development of chemosensors for the sensing of transition metal ions is one of the most active research fields with great potential for environmental and physiological applications, in particular $\mathrm{Cu}^{2+}$-sensitive systems. ${ }^{7}$ Even though great achievement in the field of colorimetric and/or fluorescent chemosensors for $\mathrm{Cu}^{2+}$ has been obtained, ${ }^{8}$ there is still a demand to develop new indicators with improved properties, especially fluorescent sensors with high efficiency in the visible spectra and with specific selectivity towards $\mathrm{Cu}^{2+}$ over other competitive metal ions. Also, due to the widespread application of $\mathrm{Pd}^{2+}$ as catalyst in organic synthesis is important the development of novel systems for its easy detection specially because a high level of residual palladium (typically 300-2000 ppm) is often found in the resultant products, which thus may be a health hazard. ${ }^{9}$

We have demonstrated that oligothiophene and arylthiophene derivatives, electronically connected to recognition sites, are efficient $\pi$-conjugated bridges for the fluorimetric and/colorimetric sensing of certain anions (e.g., $\left.\mathrm{F}^{-}, \mathrm{CN}^{-}\right)$and cations $\left(\mathrm{H}^{+}, \mathrm{Na}^{+}, \mathrm{Pd}^{2+}, \mathrm{Cu}^{2+}\right.$, 
$\left.\mathrm{Zn}^{2+}, \mathrm{Hg}^{2+}, \mathrm{Ni}^{2+}\right){ }^{5 \mathrm{~d}, 6 \mathrm{c}, 10}$ Following our current interests on colorimetric and fluorimetric chemosensors provided with heterocyclic moieties, ${ }^{5 \mathrm{~d}, 6 \mathrm{c}, 10,11}$ three novel heterocyclic systems containing arylthiophene (3-4) or bithiophene (5) bridges and one or two imidazo-benzocrown ether binding moieties were designed and synthesized.

\section{Results and discussion}

\subsection{Synthesis}

Recently the application of a mild and versatile method for 2-benzimidazole synthesis, was reported through a one step reaction involving $\mathrm{Na}_{2} \mathrm{~S}_{2} \mathrm{O}_{4}$ reduction of $o$-nitroanilines in the presence of pyridyl and quinolyl aldehydes ${ }^{12}$ in DMSO. To the best of our knowledge, this is the first time that this synthetic methodology is applied to arylthiophene and bithiophene aldehydes and an $o$-nitroaminobenzocrown ether derivative. Therefore, formyl-arylthiophenes 1a-b, diformyl-bithiophene 2 and $4^{\prime}$-amino-5'-nitrobenzo-15-crown-5 ether were used in the synthesis of imidazo-benzocrown ethers 3-5, using the synthetic methodology described above in order to evaluate the influence of the different $\pi$-conjugated bridges on the optical and sensing properties of the new compounds (Scheme 1).

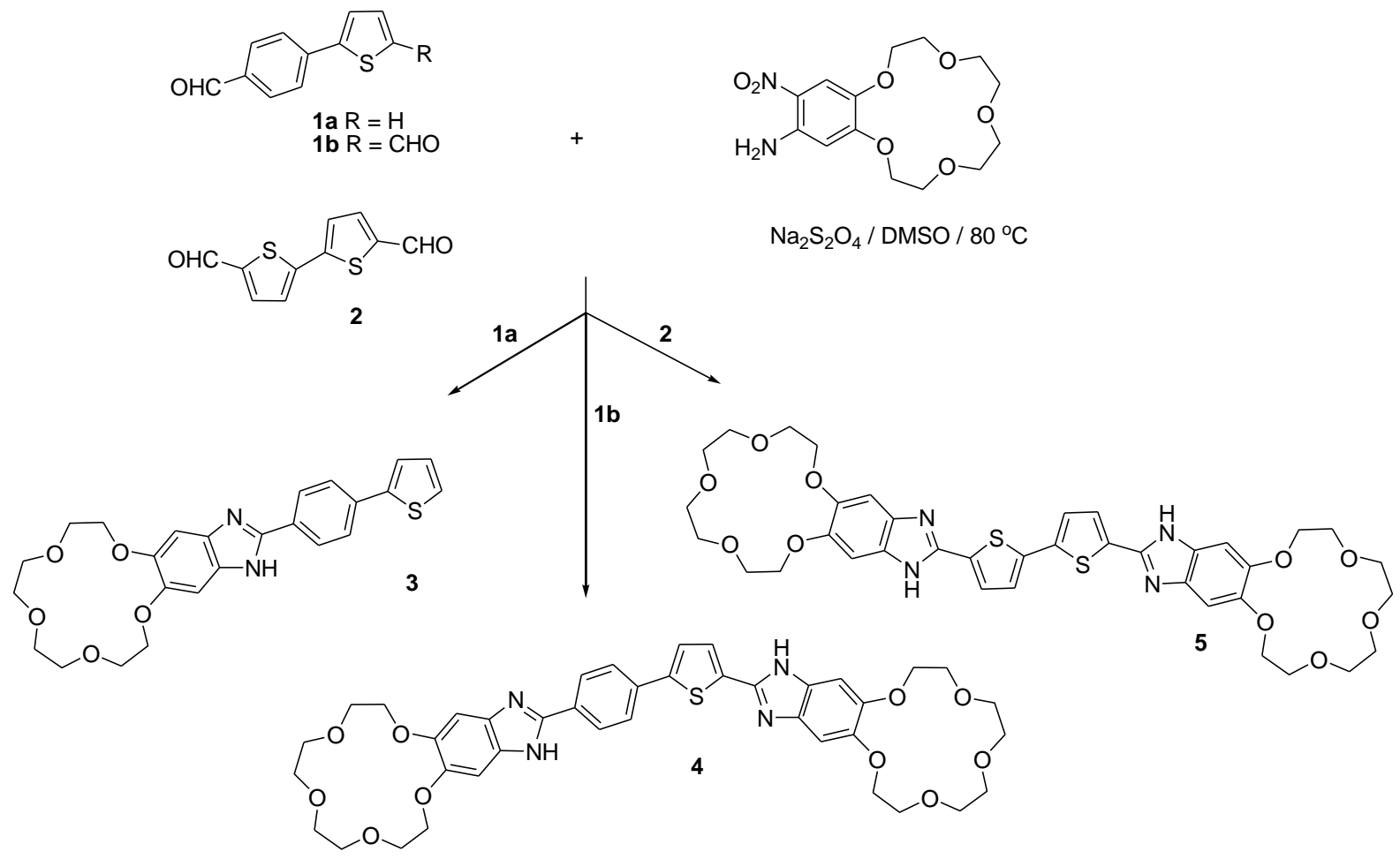

Scheme 1. Synthesis of imidazo-benzocrown ether derivatives 3-5. 
Compounds 3-5 were obtained in moderate to good yields (53-78\%) and their structures were unambiguously confirmed by their analytical and spectral data (Table 1). Aldehyde precursors were commercially available (1a) or synthesised as reported previously by some of us $(\mathbf{1 b}, \mathbf{2}){ }^{6 \mathrm{~d}, 13}$

Table 1. Yields, IR, ${ }^{1} \mathrm{H}$ NMR, UV-vis absorption and fluorescence data for imidazobenzocrown ethers 3-5.

\begin{tabular}{cccccccc}
\hline & & & & UV/Vis & \multicolumn{3}{c}{ Fluorescence } \\
\cline { 5 - 8 } Cpd. & Yield & $\begin{array}{c}\text { IR } v \\
\left(\mathrm{~cm}^{-1}\right)\end{array}$ & $\delta_{\mathrm{H}}$ & $\lambda_{\max }$ & $\lambda_{\mathrm{em}}$ & Stokes & $\Phi_{\mathrm{F}}$ \\
& $(\%)$ & & $(\mathrm{ppm})^{\mathrm{c}}$ & $(\mathrm{nm})^{\mathrm{d}}$ & $(\mathrm{nm})^{\mathrm{d}}$ & shift $(\mathrm{nm})$ & \\
\hline $\mathbf{3}$ & 64 & $3443^{\mathrm{a}}$ & ---- & 360 & 447 & 87 & 0.76 \\
$\mathbf{4}$ & 78 & $3449^{\mathrm{a}}$ & 13.45 & 395 & 500 & 105 & 0.50 \\
$\mathbf{5}$ & 53 & $3451^{\mathrm{b}}$ & 12.76 & 415 & 568 & 135 & 0.10 \\
\hline
\end{tabular}

\footnotetext{
${ }^{a}$ For the NH stretching band (recorded in nujol).

${ }^{\mathrm{b}}$ For the NH stretching band (recorded in $\mathrm{KBr}$ ).

${ }^{\mathrm{c}}$ For the $\mathrm{N} H$ proton of the imidazole ring (in DMSO- $\mathrm{d}_{6}$ ).

${ }^{\mathrm{d}}$ in MeCN/DMSO (99:1) solution.
}

\subsection{Photophysical study of imidazo-benzocrown ether derivatives 3-5.}

The electronic absorption and emission spectra of compounds 3-5 were obtained in MeCN/DMSO (99:1) solution (Table 1). The comparison of the absorption maxima of compounds 3 and $\mathbf{4}$ reveals the influence of the introduction of a second imidazo-benzocrown ether moiety as the longest wavelength transition was shifted from 360 to $395 \mathrm{~nm}$, due to more extensive electron delocalization. When comparing compounds $\mathbf{4}$ and $\mathbf{5}$, which differ in the electronic nature of the $\pi$-conjugated bridge, it can be seen that compound $\mathbf{5}$ shows a higher intramolecular charge transfer efficiency due to the substitution of a phenyl for a thiophene ring. The same trend was observed in the emission spectra for related compounds. ${ }^{14}$ The study of the fluorescence properties of compounds 3-5 showed that they are strongly emissive, with relative fluorescence quantum yields ranging from 0.10 to 0.76 (Figure 1). 
Figure 1. Absorption and emission spectra of compounds 3-5 in MeCN/DMSO (99:1), T= $298 \mathrm{~K},[3]=5.0 \times 10^{-7} \mathrm{M},[4]=5.5 \times 10^{-7} \mathrm{M},[5]=4.3 \times 10^{-7} \mathrm{M} .\left(\lambda_{\text {exc3 }}=360 \mathrm{~nm}, \lambda_{\text {exc4 }}=395\right.$ $\left.\mathrm{nm} ; \lambda_{\text {exc5 }}=415 \mathrm{~nm}\right)$.

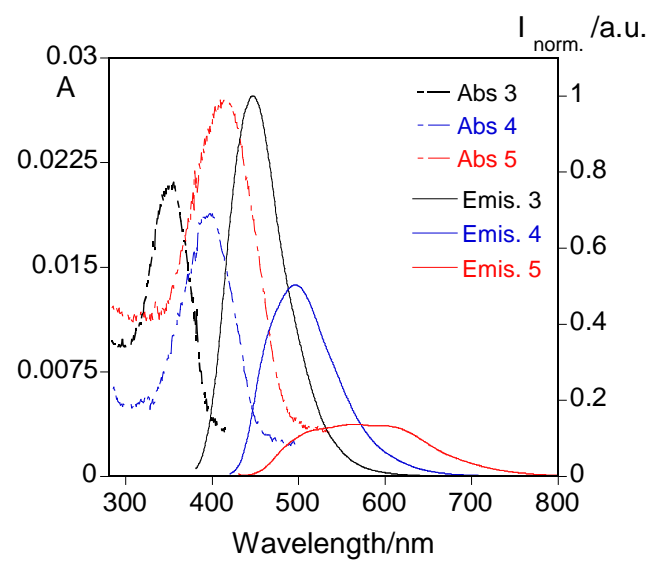

Our results revealed a decrease in the relative fluorescence quantum yield when a second imidazo-benzocrown was introduced ( 3 compared to 4 ), due to the azomethine nitrogens that contribute to the heavy atom effect concomitant with the increased degree of conjugation, ${ }^{15}$ or when a thiophene replaced a phenyl ring (4 compared to 5), with the heavy atom induced spin-orbit coupling by the sulphur atoms giving rise to a very efficient intersystem crossing mechanism, that lowers the emission. ${ }^{14,16}$ In the latter case, the decrease was larger pointing to the better quenching process produced by the sulphur atom present in the thiophene when compared to the nitrogen present in the imidazole.

\subsection{Spectrophotometric and spectrofluorimetric titrations with proton, metallic cations and fluoride anion}

Compounds 3-5 were also evaluated as chemosensors in the presence of $\mathrm{H}^{+}$and several metal cations $\left(\mathrm{Li}^{+}, \mathrm{Na}^{+}, \mathrm{K}^{+}, \mathrm{Ca}^{2+}, \mathrm{Zn}^{2+}, \mathrm{Cu}^{2+}, \mathrm{Ni}^{2+}, \mathrm{Pd}^{2+}\right.$, and $\mathrm{Hg}^{2+}$ ) in MeCN/DMSO (99:1) solutions. Having in mind our recent results concerning the sensing properties of imidazoanthraquinone derivatives bearing thiophene moieties, ${ }^{5 \mathrm{~d}}$ compounds $\mathbf{3 - 5}$ were also studied as chemosensors for the $\mathrm{F}^{-}$anion. It is known the acidity of the $\mathrm{NH}$ proton of the imidazole ring can also be tuned by changing the electronic properties of the $\pi$-conjugated bridge and our results for the signal of $\mathrm{NH}$ appearing downfield in the ${ }^{1} \mathrm{H}$ NMR spectra indicated high acidity and strong hydrogen bonding ability. 
Due to the presence of protonable imidazo units, all reported compounds were studied in the presence of $\mathrm{H}^{+}$, by titration with a solution of methanesulphonic acid in MeCN/DMSO (99:1). In general, the absorption spectra of all compounds were slightly affected, showing a red-shift of $10 \mathrm{~nm}$. Regarding the emission spectra, for $\mathbf{3}$ the intensity of the emission was practically unaffected upon addition of 50 equivalents of acid, whereas addition of the same amount of acid to $\mathbf{4}$ induced a 50\% quenching, and $\mathbf{5}$ showed a remarkable $70 \%$ increase in fluorescence intensity and a $20 \mathrm{~nm}$ blue shift. This effect can be probably due to the different aromatic bridge present in $\mathbf{4}$ and $\mathbf{5}$, bearing spacers of different planarity between both imidazo-benzo units. ${ }^{18}$ At the same time, the protonation at the nitrogen of the imidazo group resulted in a partial quenching. ${ }^{18 \mathrm{~b}}$ (Figure 2).

Figure 2. Spectrofluorimetric titration of compounds 4 (A) and 5 (B) in MeCN/DMSO (99:1) solutions as a function of added $\mathrm{CH}_{4} \mathrm{O}_{3} \mathrm{~S}$. The insets show the normalized fluorescence intensity at $500 \mathrm{~nm}$ and $535 \mathrm{~nm}$, respectively $\left([4]=4.30 \times 10^{-7} \mathrm{M}, \lambda_{\text {exc }}=395 \mathrm{~nm}\right.$; [5] = $\left.5.10 \times 10^{-7} \mathrm{M}, \lambda_{\mathrm{exc}}=415 \mathrm{~nm}\right)$.
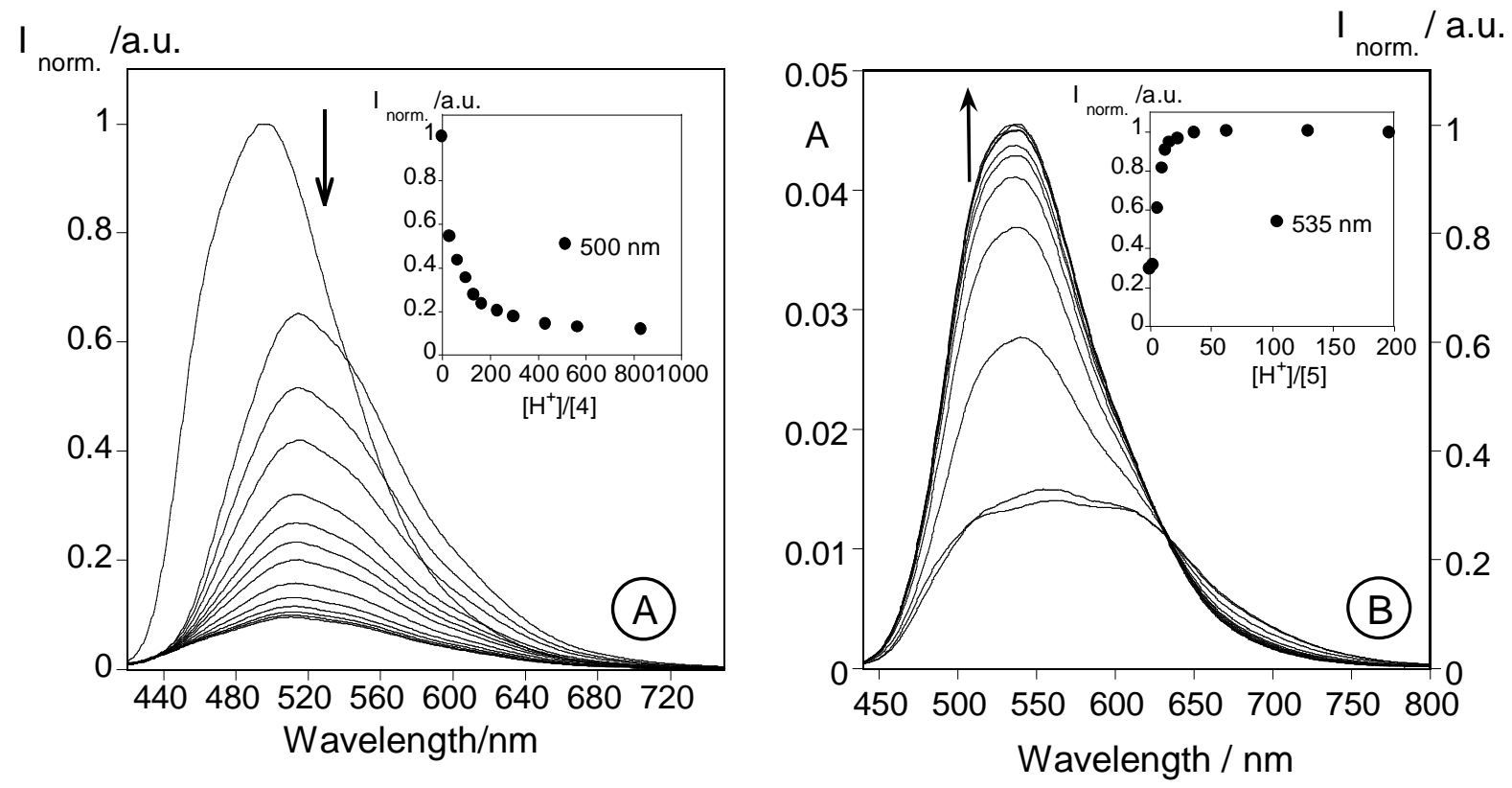

For all compounds, the fluorescence intensity was quenched upon addition of fluoride ion. For compound 3, 4000 equivalents were necessary to reach a plateau, while compounds $\mathbf{4}$ and 5 required the addition of 200 and 260 equivalents, respectively. Compound 4 appears to be the most acidic, a fact that is also confirmed by the ${ }^{1} \mathrm{H}$ NMR NH signal appearing downfield (when compared to 5). A blue shift in the emission band was observed at the same time for all 
the compounds. (Figure 3). This quenching effect can be understood as a PET effect from the lone par of electrons located at the deprotonated imidazole ring.

The sensing ability of compounds $\mathbf{3}$ to $\mathbf{5}$ was evaluated through interaction with metal ions such as alkaline $\left(\mathrm{Na}^{+}, \mathrm{Li}^{+}\right.$and $\left.\mathrm{K}^{+}\right)$, alkaline-earth $\left(\mathrm{Ca}^{2+}\right)$, and transition and post-transition metal cations $\left(\mathrm{Zn}^{2+}, \mathrm{Cu}^{2+}, \mathrm{Ni}^{2+}, \mathrm{Pd}^{2+}\right.$ and $\left.\mathrm{Hg}^{2+}\right)$ in MeCN/DMSO (99:1) by spectrophotometric and spectrofluorimetric titrations.

Figure 3. Absorption and fluorescence spectra of MeCN/DMSO (99:1) solutions of 3 (A), 4 (B) and $5(\mathrm{C})$ and fluorescence titration as a function of $\mathrm{Bu}_{4} \mathrm{NF}$ added. The insets show the

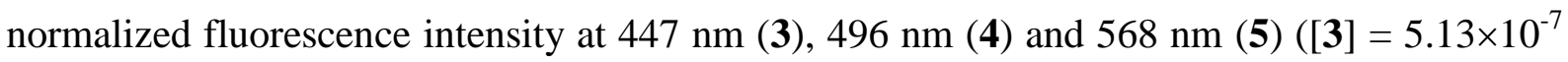
$\left.\left.\mathrm{M}, \lambda_{\mathrm{exc}}=360 \mathrm{~nm} ;[4]=4.30 \times 10^{-7} \mathrm{M}, \lambda_{\mathrm{exc}}=395 \mathrm{~nm}\right) .[5]=5.10 \times 10^{-7} \mathrm{M}, \lambda_{\mathrm{exc}}=415 \mathrm{~nm}\right)$.
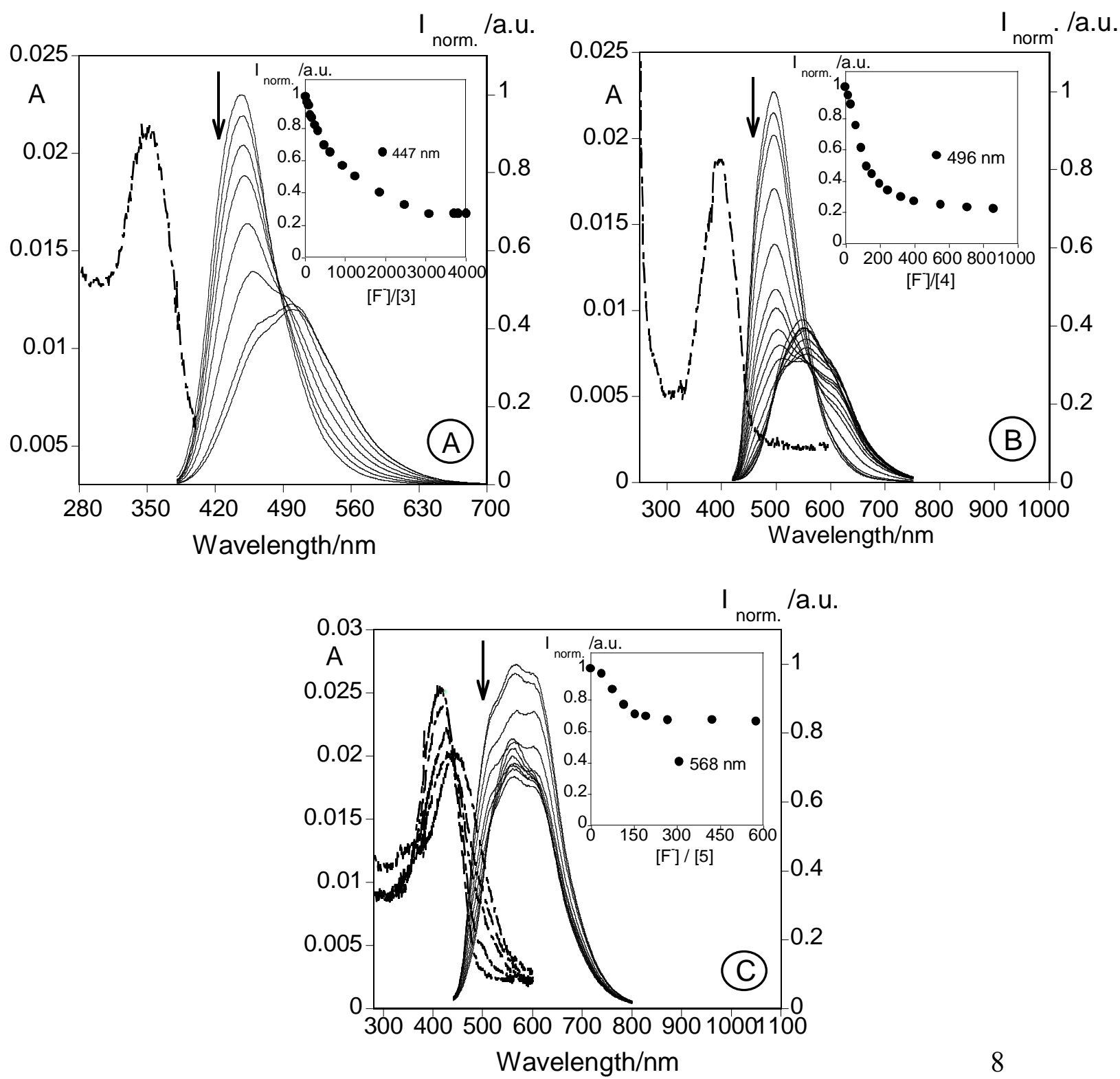
The addition of up to 2000 equivalents of $\mathrm{Na}^{+}, \mathrm{Li}^{+}$and $\mathrm{K}^{+}$metal ions practically does not induce spectral changes, producing only a $10 \%$ quenching of the fluorescence emission. However, in compound 5 the addition of the same amount of $\mathrm{Na}^{+}$resulted in a blue-shift in the emission band and an intensity increase of $20 \%$ reaching a plateau (Figure 4). It is well known that the benzo-15-crown-5-ether quelating unit is used specifically for $\mathrm{Na}^{+}$sensing. However, our results suggest that the high delocalized charge presented in these conjugated systems could modulate the interaction with the crown ether resulting in small changes in the ground state, as well as in the excited state.

Figure 4. Absorption and fluorescence spectra of MeCN/DMSO (99:1) solutions of $3(\mathrm{~A}), 4$ (B) and 5 (C) after addition of 2000 equivalents of $\mathrm{NaBF}_{4} ; \mathrm{LiBF}_{4} ; \mathrm{KBF}_{4} ; \mathrm{Ca}\left(\mathrm{CF}_{3} \mathrm{SO}_{3}\right)_{2}$ and $\mathrm{Zn}\left(\mathrm{CF}_{3} \mathrm{SO}_{3}\right)_{2}$ in $\mathrm{CH}_{3} \mathrm{CN}$. ([3] $=5.13 \times 10^{-7} \mathrm{M}, \lambda_{\text {exc }}=360 \mathrm{~nm} ;[4]=4.30 \times 10^{-7} \mathrm{M}, \lambda_{\text {exc }}=395$ $\left.\mathrm{nm} ;[5]=5.10 \times 10^{-7} \mathrm{M}, \lambda_{\mathrm{exc}}=415 \mathrm{~nm}\right)$.
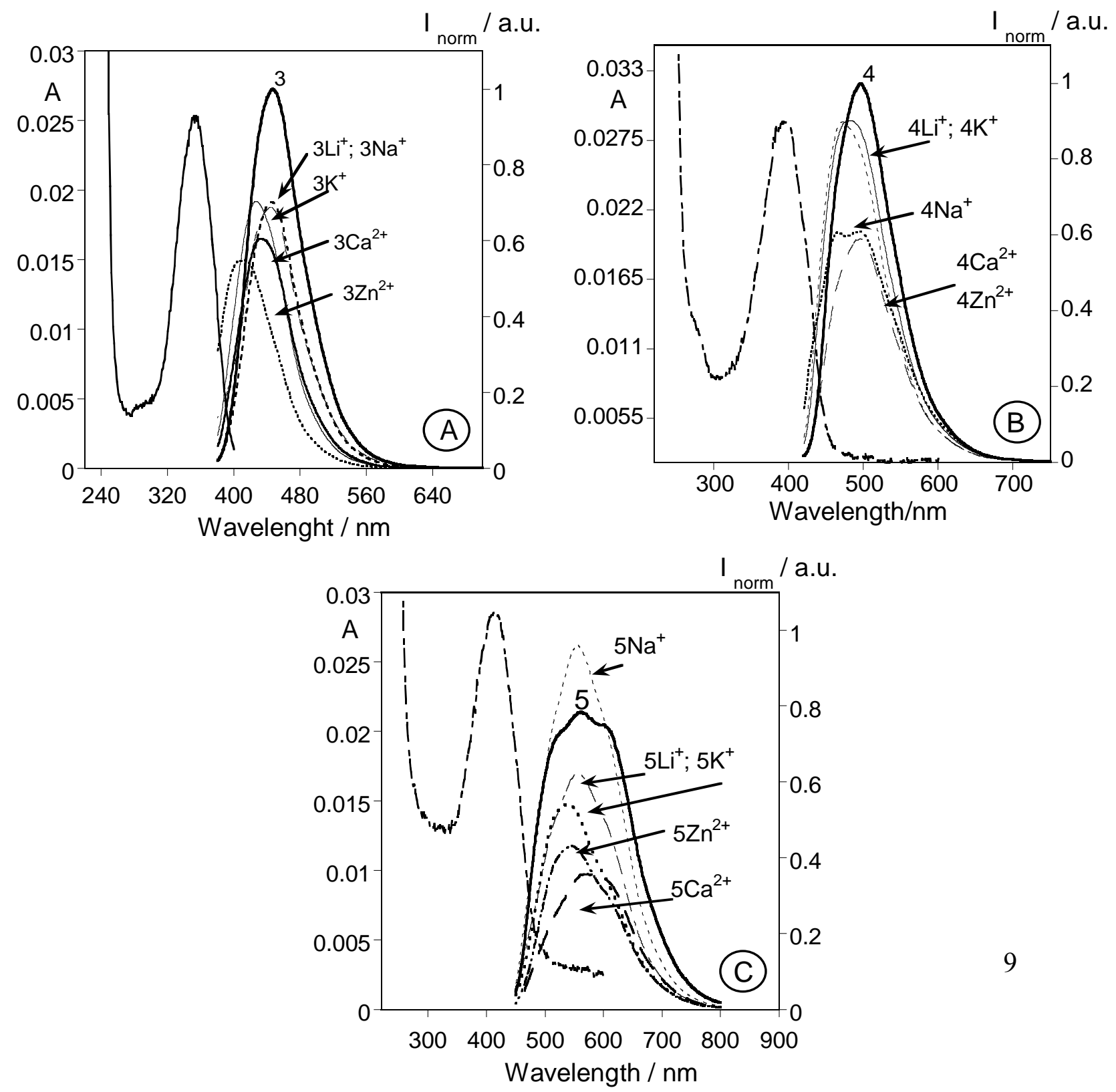
In general, the interaction of compounds 3-5 with $\mathrm{Zn}^{2+}, \mathrm{Ni}^{2+}$ and $\mathrm{Hg}^{2+}$ show a very small blue shift, between 10 and $15 \mathrm{~nm}$, in the absorption band. In the case of $\mathrm{Zn}^{2+}$ that normally produces a CHEF (chelation enhancement of fluorescence) effect with polyamine systems, it was observed a 40 to $50 \%$ quenching of emission in all cases. Similar findings had been published for compounds bearing a coordinative aromatic nitrogen atom. ${ }^{17}$ Concerning $\mathrm{Ni}^{2+}$ and $\mathrm{Hg}^{2+}$, it was observed the same quenching effect of about $50 \%$ with compound 4 .

The strongest interaction observed for the new compounds reported was found in the presence of $\mathrm{Pd}^{2+}$ and $\mathrm{Cu}^{2+}$.

A CHEQ (chelation enhancement of the quenching) effect in the fluorescence emission for these both metals was observed (Figure 5 and Figure 6). Moreover, a blue shift was observed when $\mathrm{Cu}^{2+}$ was added to ligand 5 (Figure 6). The stronger interaction was detected for compound 4 in the presence of $\mathrm{Cu}^{2+}$, where only 25 equivalents are enough to quench the emission. In the case of compounds $\mathbf{3}$ and $\mathbf{5}$, up to 40 and 60 equivalents were necessary, respectively.

Figure 5. Absorption spectra of MeCN-DMSO (99:1) solutions of 3 (A), 4 (B) and 5 (C) and fluorescence titration as a function of added $\mathrm{Pd}\left(\mathrm{CH}_{3} \mathrm{CN}\right)_{4} \mathrm{BF}_{4}$. The insets show the normalized fluorescence intensity at $447 \mathrm{~nm}(\mathbf{3}), 500 \mathrm{~nm}(\mathbf{4})$ and $568 \mathrm{~nm}(\mathbf{5}) .(\mathrm{T}=298 \mathrm{~K}$; [3] = 5.13.10 $\left.\mathrm{M}, \lambda_{\mathrm{exc}}=360 \mathrm{~nm} ;[\mathbf{4}]=5.10 \cdot 10^{-7} \mathrm{M}, \lambda_{\mathrm{exc}}=395 \mathrm{~nm} ;[\mathbf{5}]=4.30 \cdot 10^{-7} \mathrm{M}, \lambda_{\mathrm{exc}}=415 \mathrm{~nm}\right)$.
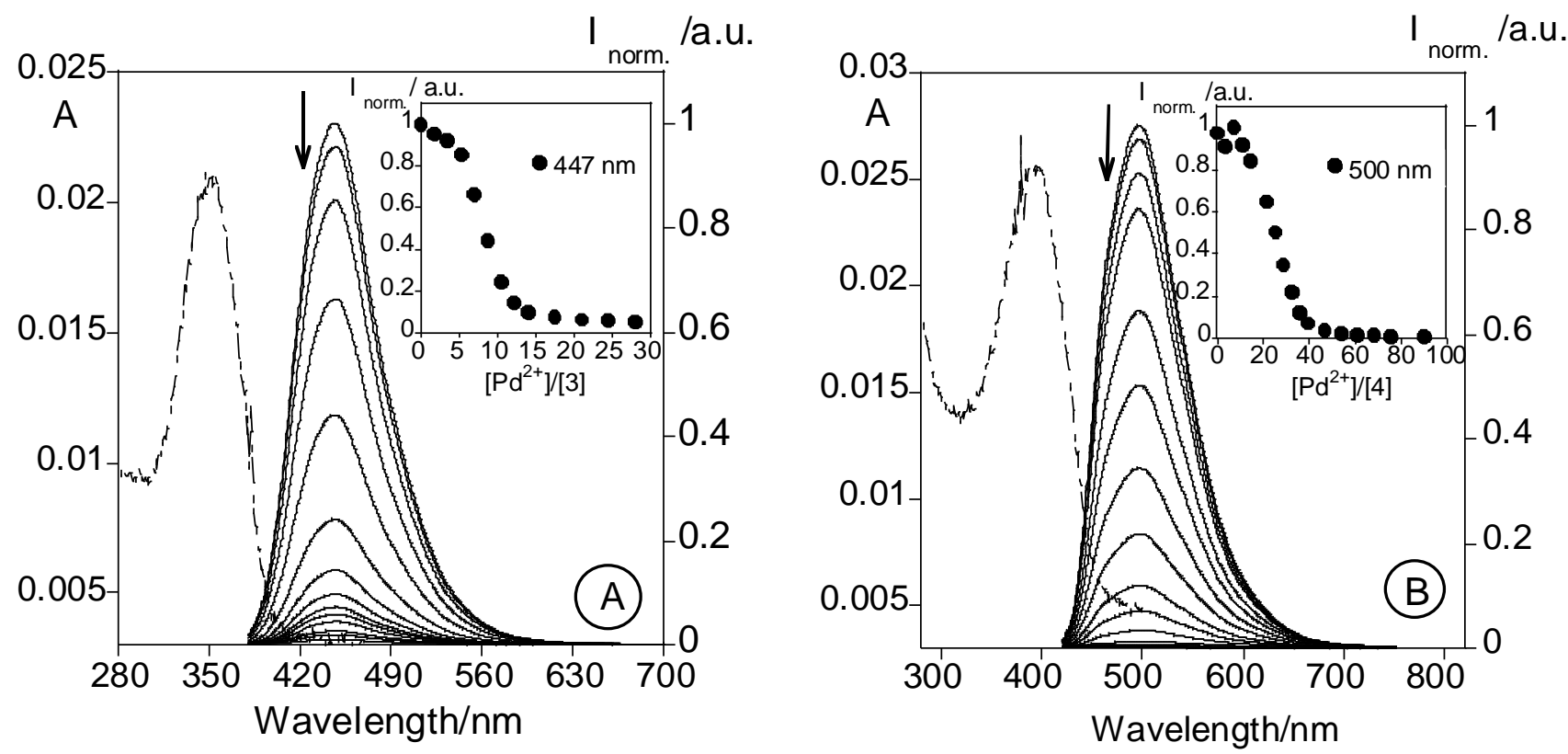


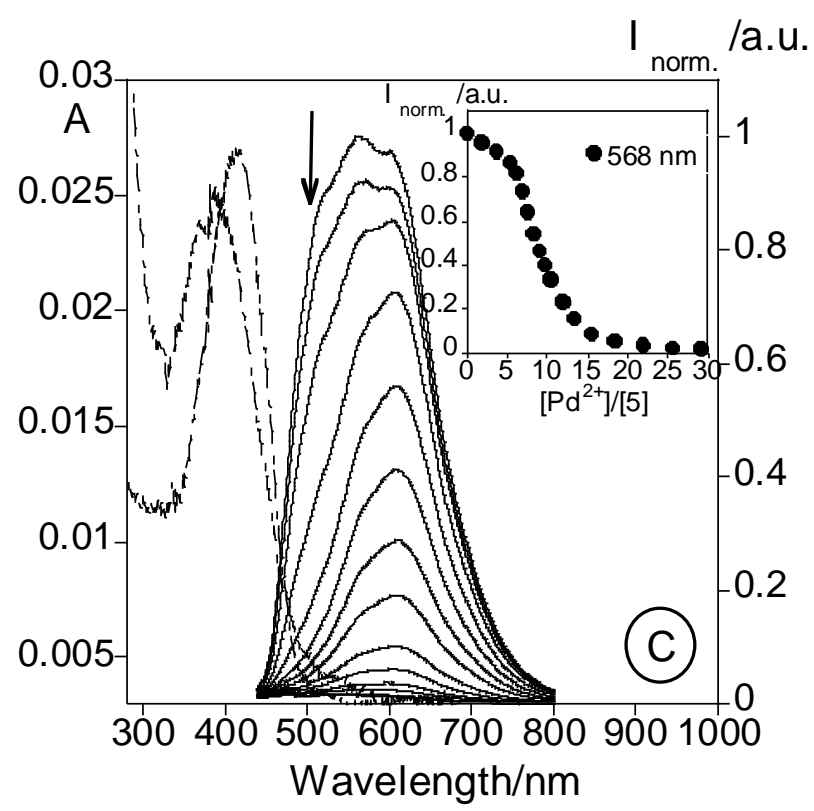

Figure 6. Absorption and fluorescence spectra of MeCN/DMSO (99:1) solutions of 3 (A), 4 (B) and 5 (C) as a function of added $\mathrm{Cu}_{(}\left(\mathrm{CF}_{3} \mathrm{SO}_{3}\right)_{2}$. The insets show the normalized

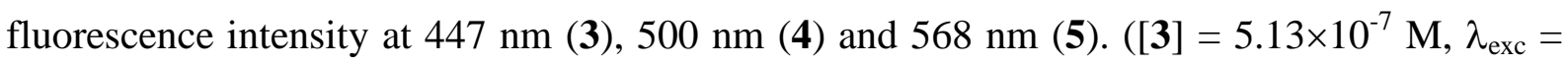
$\left.360 \mathrm{~nm} ;[4]=4.30 \times 10^{-7} \mathrm{M}, \lambda_{\text {exc }}=395 \mathrm{~nm},[5]=5.10 \times 10^{-7} \mathrm{M}, \lambda_{\text {exc }}=415 \mathrm{~nm}\right)$.
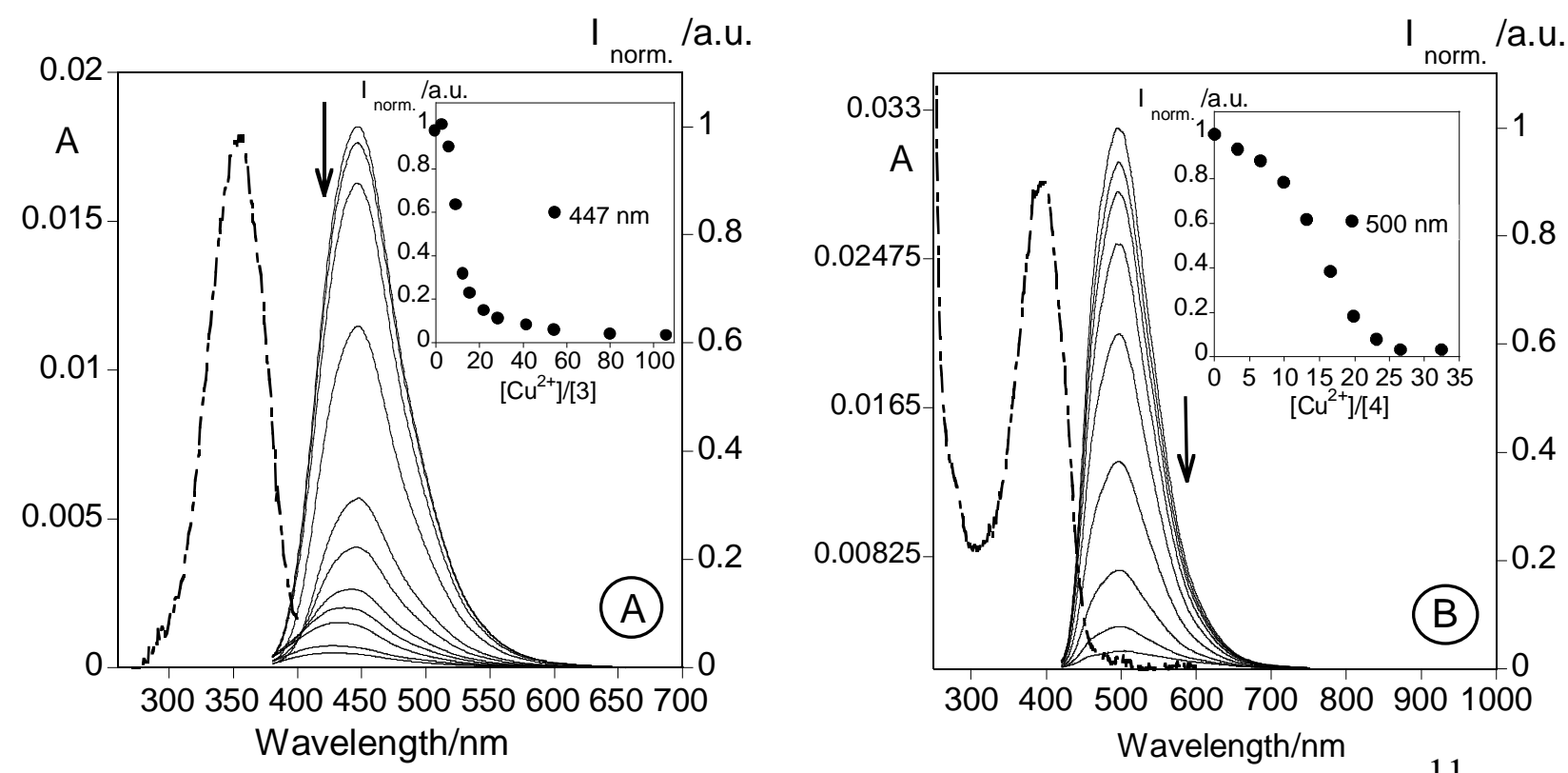


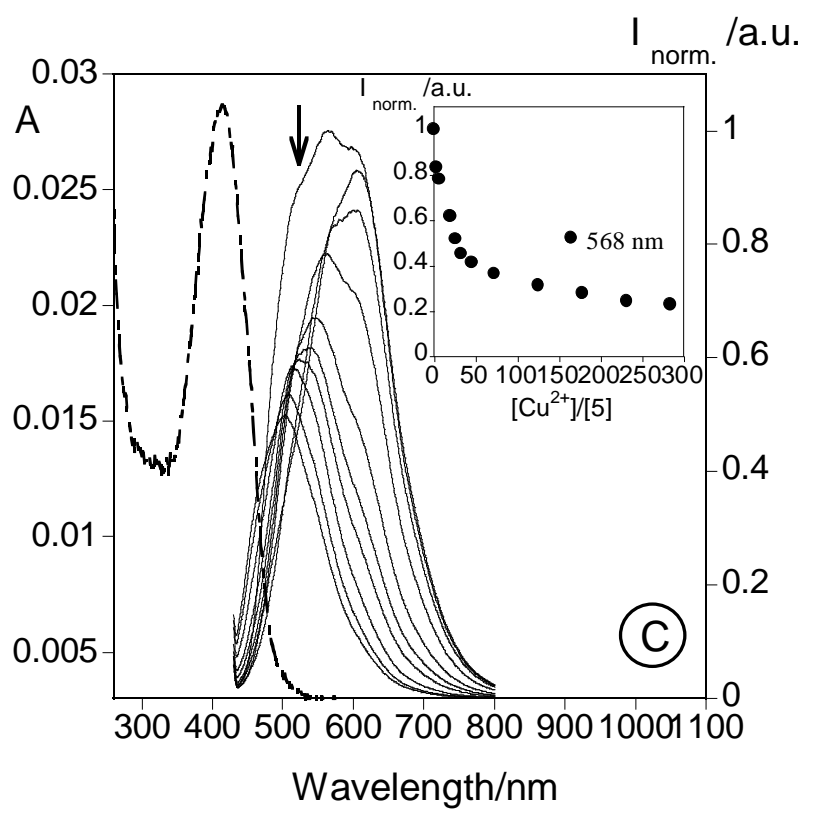

Insets of Figure 5 show the metal ion titration followed at the maximum of the emission band. Inspection of these figures shows that compound $\mathbf{3}$ and $\mathbf{5}$ are totally quenched upon the addition of 15 equivalents of $\mathrm{Pd}^{2+}$, while in compound 4, 40 equivalents to obtain the same quenching effect were necessary. In summary, compounds $\mathbf{3}$ and $\mathbf{5}$ appear to be quenched more efficiently by $\mathrm{Pd}^{2+}$ while compound 4 by $\mathrm{Cu}^{2+}$. This result turns out from the involvement of the nitrogen atom from the imidazole ring and the sulphur atoms in compounds $\mathbf{4}$ and $\mathbf{5}$,both perfectly design to produce a chelate ring.

The quenching effect observed could be attributed to an energy transfer quenching of the $\pi^{*}$ emissive state through low-lying metal-centered unfilled d-orbitals for $\mathrm{Pd}^{2+}$ and $\mathrm{Cu}^{2+}$, and to an intersystem crossing mechanism due to the heavy atom effect. ${ }^{19}$

Taking into account the non coordinative counterions used for all metal complexes, $\left(\mathrm{CF}_{3} \mathrm{SO}_{3}{ }^{-}\right.$ or $\mathrm{BF}_{4}{ }^{-}$) the hypothesis of $2: 1 \mathrm{M} / \mathrm{L}$ molar ratio could be perfectly predicted as the acetonitrile can acts as a secondary ligand. The stoichiometry of the complexes was obtained through Job's plot. For example, follow the absorption band in the ligand 3 the stoichiometry 1:2 L:M was deduced in the presence of $\mathrm{Pd}^{2+}$ (Figure 7). 
Figure 7. Job's plot of compound 3 in the presence of $\mathrm{Pd}^{2+}$.

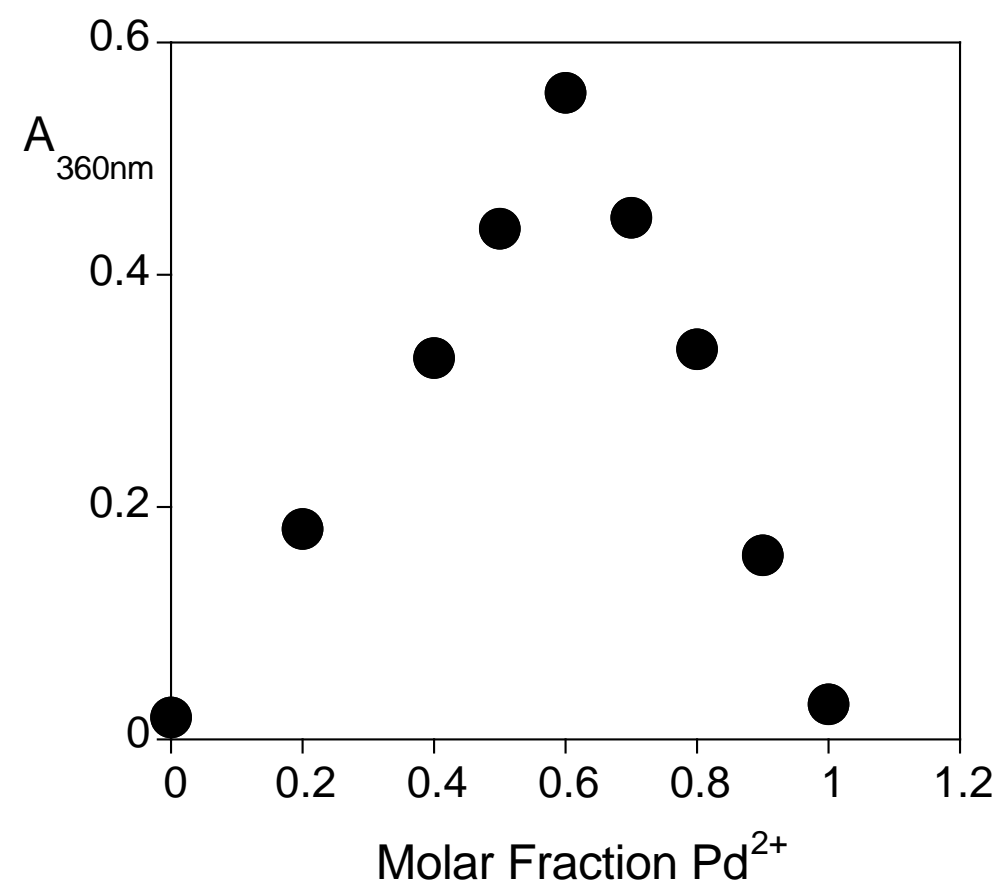

The complexation constants of compounds 3-5, were obtained from the spectroscopic titrations using the Hypspec program. ${ }^{20}$ The highest constant for $\mathrm{Pd}^{2+}$ ions was obtained for compound $3\left(\log \mathrm{K}_{\mathrm{ass}}=11.07 \pm 0.01\right)$ and the value decreased for the other two host systems in the sequential order $\mathbf{3}>\mathbf{4}>\mathbf{5}$. In the case of $\mathrm{Cu}^{2+}$, similar values were obtained for all systems (from $\log \mathrm{K}_{\mathrm{ass}}=10.32 \pm 0.01$ to $\log \mathrm{K}_{\mathrm{ass}}=10.93 \pm 0.01$ ). For both metal ions, the experimental values suggest the formation of a dinuclear complex. The study of the interaction with fluoride ion indicated a mononuclear species, exhibiting lower constant values in all cases (Table 2). 
Table 2. Association constants for benzocrown ethers 3-5 in the presence of $\mathrm{F}^{-}, \mathrm{Pd}^{2+}$ and $\mathrm{Cu}^{2+}$ in MeCN/DMSO (99:1).

\begin{tabular}{ccc}
\hline Cpd. & Guest & $\log \mathrm{K}_{\text {ass }}(\mathrm{M}: \mathrm{L})$ \\
\hline \multirow{3}{*}{$\mathbf{3}$} & $\mathrm{F}^{-}$ & $3.27 \pm 0.01(1: 1)$ \\
& $\mathrm{Cu}^{2+}$ & $10.32 \pm 0.01(2: 1)$ \\
& $\mathrm{Pd}^{2+}$ & $11.07 \pm 0.01(2: 1)$ \\
& $\mathrm{F}^{-}$ & $4.09 \pm 0.01(1: 1)$ \\
$\mathbf{4}$ & $\mathrm{Cu}^{2+}$ & $10.78 \pm 0.01(2: 1)$ \\
& $\mathrm{Pd}^{2+}$ & $9.72 \pm 0.03(2: 1)$ \\
& $\mathrm{F}^{-}$ & $4.10 \pm 0.02(1: 1)$ \\
& $\mathrm{Cu}^{2+}$ & $10.93 \pm 0.01(2: 1)$ \\
& $\mathrm{Pd}^{2+}$ & $10.60 \pm 0.01(2: 1)$ \\
\hline
\end{tabular}

\section{Conclusions}

In conclusion, novel imidazo benzocrown ether-based ionophores bearing arylthienyl and bithienyl $\pi$-conjugated bridges 3-5 were synthesized in moderate to good yields and evaluated as fluorimetric sensors. Selectivity and sensitivity for $\mathrm{Cu}^{2+}$ and $\mathrm{Pd}^{2+}$ was observed for all systems. Moreover, systems $\mathbf{4}$ and $\mathbf{5}$ proved to be efficient proton and also basic anion sensors, due to changes in emission after deprotonation of the imidazole $\mathrm{NH}$ by the fluoride ion.

\section{Experimental}

\subsection{Synthesis general}

Progress of the reaction was monitored by thin layer chromatography $(0.25 \mathrm{~mm}$ thick precoated silica plates: Merck Fertigplatten Kieselgel 60F254), while purification was effected by silica gel column chromatography (Merck Kieselgel 60; 230-400 mesh). NMR spectra were obtained on a Varian Unity Plus Spectrometer at an operating frequency of 300 $\mathrm{MHz}$ for ${ }^{1} \mathrm{H}$ and $75.4 \mathrm{MHz}$ for ${ }^{13} \mathrm{C}$ or a Bruker Avance III 400 at an operating frequency of $400 \mathrm{MHz}$ for ${ }^{1} \mathrm{H}$ and $100.6 \mathrm{MHz}$ for ${ }^{13} \mathrm{C}$, using the solvent peak as internal reference. The solvents are indicated in parenthesis before the chemical shift values ( $\delta$ relative to TMS). Mps were determined on a Gallenkamp apparatus and are uncorrected. Infrared spectra were 
recorded on a BOMEM MB 104 spectrophotometer. Mass spectrometry analyses were performed at the C.A.C.T.I. -Unidad de Espectrometria de Masas of the University of Vigo, Spain. Elemental analysis was carried out on a Leco CHNS-932.

4-Amino-5-nitrobenzo-15-crown-5 was purchased from Aldrich and used as received. The synthesis of 2-(4'-formylphenyl)-thiophene, 2-formyl-5-(4'-formylphenyl)-thiophene and 5,5'-diformyl-2,2'-bithiophene has been described elsewhere. ${ }^{6 \mathrm{~d}, 13}$

\subsection{General procedure for the synthesis of compounds 3-5}

A solution of 4-amino-5-nitrobenzo-15-crown-5 and the formylated precursor (molar ratio 1:1 for the synthesis of compound 3 and molar ratio 2:1 for the preparation of compounds 4-5 ) in DMSO (3 mL) was treated with $\mathrm{Na}_{2} \mathrm{~S}_{2} \mathrm{O}_{4}$ (3 equiv), dissolved in a small volume of water, and heated at $80{ }^{\circ} \mathrm{C}$ with stirring for $15 \mathrm{~h}$. The mixture was then cooled to room temperature and the product precipitated during neutralization with $\mathrm{NH}_{4} \mathrm{OH} 5$ M. The precipitate was filtered, washed with water and diethyl ether and dried to give the expected product.

Crown ether 3. Yellow solid (64\%). Mp: 291.5-293.0 ${ }^{\circ} \mathrm{C}$. IR (Nujol) v 3443, 2923, 2855, 1639, 1609, 1464, 1377, 1293, 1256, 1219, 1209, 1173, 1139, 1081, 1050, 1008, 983, 945, 849, $826 \mathrm{~cm}^{-1} .{ }^{1} \mathrm{H}$ NMR (DMSO-d $\left.)_{6}\right) 3.63\left(\mathrm{~s}, 8 \mathrm{H}, 4 \mathrm{xCH}_{2}\right), 3.82\left(\mathrm{~s}, 4 \mathrm{H}, 2 \mathrm{xCH}_{2}\right), 4.13(\mathrm{~s}, 4 \mathrm{H}$, 2xCH $\mathrm{CH}_{2}$ ), 7.19-7.22 (m, 3H, 4"-H, 4-H and 5-H), 7.67 (dd, 1H, J=4.5 and 0.9 Hz, 5"-H), 7.71 (dd, 1H, $J=2.7$ and $0.9 \mathrm{~Hz}, 3 "-\mathrm{H}), 7.93$ (d, 2H, $J=8.7 \mathrm{~Hz}, 2^{\prime}-\mathrm{H}$ and 6'-H), 8.13 (d, 2H, $J=8.7$

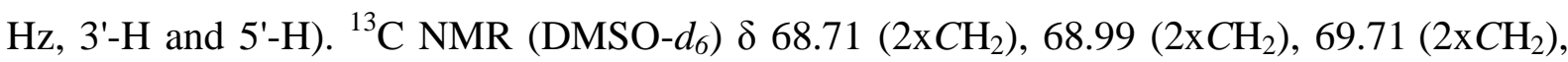
$70.52\left(2 \mathrm{xCH}_{2}\right), 97.93$ (C4 and C5), 124.12 (C4'), 125.42 (C3"), 126.04 (C2' and C6'), 127.39 (C5"), 127.61 (C3' and C5'), 128.14 (C3a and C5a), 128.97 (C4"), 136.53 (C1'), 141.99 (C2"), 147.06 (C2), 148.16 (C4a and C4b). MS (FAB) m/z (\%): $467\left([\mathrm{M}+\mathrm{H}]^{+}, 60\right), 466\left(\mathrm{M}^{+}, 17\right), 308$ (13), 307 (40), 289 (17), 155 (32), 154 (100). HRMS: (FAB) $m / z$ (\%) for $\mathrm{C}_{25} \mathrm{H}_{27} \mathrm{~N}_{2} \mathrm{O}_{5} \mathrm{~S}$; calcd 467.1641; found 467.1654.

Crown ether 4. Brown solid (78\%). Mp: 246.5-248.9 ${ }^{\circ} \mathrm{C}$. IR (Nujol) v 3449, 2930, 2842, 1633 , 1593, 1467, 1378, 1284, 1121, 1053, 938, 844, 811, $722 \mathrm{~cm}^{-1} .{ }^{1} \mathrm{H}$ NMR (DMSO-d $\left.d_{6}\right) 3.65$ (s, $16 \mathrm{H}, 4 \times \mathrm{xCH}_{2}$ ), $3.82\left(\mathrm{~s}, 8 \mathrm{H}, 2 \mathrm{xCH}_{2}\right), 4.11$ (s, 8H, 2xCH ), 7.14 (s, 2H, 4-H and 5-H), 7.18 (s, 2H, 4-H and 5-H), 7.71 (d, 1H, J=4.0 Hz, 3"-H), 7.87 (d, 2H, J=8.8 Hz, 2'-H and 6'-H), 7.92 $\left(\mathrm{d}, 1 \mathrm{H}, J=4.0 \mathrm{~Hz}, 4^{\prime \prime}-\mathrm{H}\right), 8.27$ (d, 2H, J=8.4 Hz, 3'-H and $\left.5^{\prime}-\mathrm{H}\right), 13.45$ (br s, $\left.1 \mathrm{H}, \mathrm{NH}\right) .{ }^{13} \mathrm{C}$ NMR (DMSO- $\left.d_{6}\right) \delta 68.46\left(4 \mathrm{xCH}_{2}\right), 68.52\left(4 \mathrm{xCH}_{2}\right), 69.13\left(4 \mathrm{xCH}_{2}\right), 69.65\left(2 \mathrm{xCH}_{2}\right), 69.73$ $\left(2 \times \mathrm{CH}_{2}\right), 125.40,125.69,126.89,127.22,128.62,133.76,134.20,143.41,145.38,145.84$, 
146.22, 148.81. MS (FAB) $m / z(\%): 795\left([\mathrm{M}+\mathrm{Na}]^{+}, 100\right), 773\left([\mathrm{M}+\mathrm{H}]^{+}, 21\right), 636(12), 517$ (10). HRMS: (FAB) $m / z$ (\%) for $\mathrm{C}_{40} \mathrm{H}_{45} \mathrm{~N}_{4} \mathrm{O}_{10} \mathrm{~S}$; calcd 773.2856; found 773.2866.

Crown ether 5. Brown solid (53\%). Mp: 260.5-263.0 ${ }^{\circ} \mathrm{C}$. IR (KBr) v 3451, 3078, 2922, 2855 , 1655, 1490, 1439, 1345, 1297, 1226, 1130, 1053, 943, $799 \mathrm{~cm}^{-1} .{ }^{1} \mathrm{H}$ NMR (DMSO-d 6 ) 3.63 (s, 16H, 8xCH $\left.\mathrm{CH}_{2}\right), 3.82\left(\mathrm{~s}, 8 \mathrm{H}, 4 \mathrm{xCH}_{2}\right), 4.08$ (s, 8H, 4xCH $\mathrm{x}_{2}, 6.99$ (s, 2H, 2x4-H), 7.17 (s, 2H, 2x5-H), 7.45 (d, 2H, J=4.0 Hz, 2x3'-H), 7.68 (d, 2H, J=4.0 Hz, 2x4'-H), 12.75 (s, 2H, 2xNH).

${ }^{13} \mathrm{C}$ NMR (DMSO- $\left.d_{6}\right) \delta 68.88\left(8 \times \mathrm{xH}_{2}\right), 69.79\left(4 \mathrm{x} C \mathrm{H}_{2}\right), 70.37\left(4 \times \mathrm{CH}_{2}\right), 95.88(2 \mathrm{xC} 4$ and 2xC5), 125.35 (2xC3'), 126.30 (2xC4'), 127.81 (2xC3a and 2xC5a), 133.27 (2xC2'), 136.86 (2xC5'), $144.92(2 \times C 2), 146.04$ (2xC4a and 2xC4b). MS (FAB) $\mathrm{m} / z(\%): 779\left([\mathrm{M}+\mathrm{H}]^{+}, 10\right)$, 501 (34), 307 (34), 282 (22), 155 (32), 154 (100). HRMS: (FAB) $m / z$ (\%) for $\mathrm{C}_{38} \mathrm{H}_{43} \mathrm{~N}_{4} \mathrm{O}_{10} \mathrm{~S}_{2}$; calcd 779.2421; found 779.2394.

\subsection{Spectrophotometric and spectrofluorimetric titrations of compounds 3-5}

UV-vis absorption spectra $(220-800 \mathrm{~nm})$ were obtained using a Perkin Elmer lambda 35 spectrophotometer and fluorescence emission on a Perkin Elmer LS45. The linearity of the fluorescendce emission vs. concentration was checked in the concentration range used $\left(10^{-4}\right.$ $\left.10^{-6} \mathrm{M}\right)$. A correction for the absorbed light was performed when necessary. All spectrofluorimetric titrations were performed as follows: stock solutions of compounds 3-5 (ca. $10^{-3} \mathrm{M}$ ) were prepared in a $50 \mathrm{~mL}$ volumetric flask and diluting to the mark with MeCN/DMSO (99:1) UVA-sol. The titration solutions were prepared by appropriate dilution of stock solutions. Titrations of compounds 3-5 were carried out by addition of microliter amounts of standard solutions of the ions (cations or anions) in acetonitrile.

The organic solvents were purified by standard methods. ${ }^{21} \mathrm{CH}_{4} \mathrm{SO}_{3}, \mathrm{Bu}_{4} \mathrm{NOH}, \mathrm{NaBF}_{4}, \mathrm{KBF}_{4}$, $\mathrm{LiBF}_{4}, \mathrm{Ca}\left(\mathrm{CF}_{3} \mathrm{SO}_{3}\right)_{2}, \mathrm{Zn}\left(\mathrm{BF}_{4}\right)_{2}, \mathrm{Cu}\left(\mathrm{BF}_{4}\right)_{2}, \mathrm{Ni}\left(\mathrm{BF}_{4}\right)_{2}, \mathrm{Pd}\left(\mathrm{BF}_{4}\right)_{2}, \mathrm{Hg}\left(\mathrm{CF}_{3} \mathrm{SO}_{3}\right)_{2}$, and $\mathrm{Bu}_{4} \mathrm{NF}$ were purchased from Strem Chemicals, Sigma Aldrich and Solchemar. All were used without previous purification. $\mathrm{CH}_{4} \mathrm{SO}_{3}$ was used to change the acidity conditions of the MeCN/DMSO solutions. Luminescence quantum yields were measured using a solution of quinine sulfate in sulfuric acid $(0.1 \mathrm{M})$ as standard $\left[\phi_{\mathrm{F}}=0.54\right] .{ }^{22}$ All measurements were conducted at $298 \mathrm{~K}$.

\section{Acknowledgments}

Thanks are due to the Fundação para a Ciência e Tecnologia (Portugal) and FEDER for financial support through the Centro de Química and Centro de Física- Universidade do Minho, and Project PTDC/QUI/66250/2006 (FCOMP-01-0124-FEDER-007428), PhD grant 
to R.M.F. Batista (SFRH/BD/36396/2007) and Postdoctoral grant to E. Oliveira (SFRH/BPD/72557/2010). The NMR spectrometer Bruker Avance III 400 is part of the National NMR Network and was purchased within the framework of the National Program for Scientific Re-equipment, contract REDE/1517/RMN/2005 with funds from POCI 2010 (FEDER) and FCT. C. L. Thanks Xunta de Galicia, Spain, for the Isidro Parga Pondal Research Program.

\section{References}

[1] (a) Gale, P. A., Ed.; Special issue: 35 years of Synthetic Anion Receptor Chemistry. Coord. Chem. Rev. 2003, 240, 1-2. (b) Martínez-Manêz, R.; F. Sancenón; Chem. Rev. 2003, 103, 4419-4476. (c) Martínez-Manêz, R.; Sancenón; F. J. Fluoresc. 2005, 15, $267-$ 285. (d) Martínez-Manêz, R.; Sancenón; F. Coord. Chem. Rev. 2006, 250, 3081-3093; (e) Moragues, M. E.; Martínez-Manêz, R.; Sancenón; F. Chem. Soc. Rev. 2011, 40, $2593-$ 2643.

[2] (a) Prodi, L.; Bolletta, F.; Montalti, M.; Zaccheroni, N. Coord. Chem. Rev. 2000, 205, 5983; (b) Valeur, B.; Leray, I. Coord. Chem. Rev. 2000, 205, 3-40; (c) de Silva, A. P.; Fox, D. B.; Huxley, A. J. M.; Moody, T. S. Coord. Chem. Rev. 2000, 205, 41-57.

[3] (a) Special issue on Luminescent Sensors. Coord. Chem. Rev. 2000, 205. (b) New Trends in Fluorescence Spectroscopy: Applications to Chemical and Life Sciences; Valeur, B., Brochon, J.-C., Eds.; Springer: Berlin, 2001. (c) Rurack, K.; Resch-Genger, U. Chem. Soc. Rev. 2002, 31, 116.

[4] (a) Gokel, G.W.; Leevy, W. M.; Weber, M. E. Chem. Rev. 2004 104, 2723-2750. (b) Fery-Forgues, S.; Al-ali, F.; J. Photochem. Photobiol. C Photochem. Rev. 2004, 5, 139153. (c) Arias, J.; Bardají, M.; Espinet, P.; J. Organomet. Chem. 2006, 691, 4990-4990. (d) Fedorova, O. A.; Lukovskaya, E.; Mizerev, A.; Fedorov, Y.; Bobylyova, A.; Maksimov, A.; Moiseeva, A.; Anisimov, A.; Jonusauskas, G.; J. Phys. Org. Chem. 2010, 23, 246-254 and references cited therein.

[5] For some examples see: (a) Peng, X.; Wu, Y.; Fan, J.; Tian, M.; Han, Keli J. Org. Chem. 2005, 70, 10524-10531. (b) Boiocchi, M.; Del Boca, L.; Gómez, D. E.; Fabbrizzi, L.; Licchelli, M.; Monzani, E. Chem. Eur. J. 2005, 11, 3097-3104. (c) Amendola, V.; Esteban-Gomez, D.; Fabbrizzi, L.; Liccelli, M.; Sancenón, F.; Taglietti, A. Coord. Chem. Rev. 2006, 250, 1451-1470. (d) Batista, R. M. F.; Oliveira, E.; Costa, S. P. G.; Lodeiro, C.; Raposo, M. M. M. Org. Lett. 2007, 9, 3201-3204. 
[6] (a) Zhang, M.; Li, M.; Zhao, Q.; Li, F.; Zhang, D.; Zhang, J.; Yi, T.; Huang, C. Tetrahedron Lett. 2007, 48, 2329-2333. (b) Zhang, M.; Li, M. Y.; Li, F. Y.; Cheng, Y. F.; Zhang, J. P.; Yi, T.; Huang, C. H. Dyes Pigments 2008, 77, 408-414. (c) Oliveira, E.; Batista, R. M. F.; Costa, S. P. G.; Lodeiro, C.; Raposo, M. M. M. Inorg. Chem. 2010, 49, 10847-10857. (d) Batista, R. M. F.; Costa, S. P. G.; Belsley, M.; Lodeiro, C.; Raposo, M. M. M. Tetrahedron 2008, 64, 9230-9238.

[7] (a) Krämer, R. Angew. Chem., Int. Ed. 1998, 37, 772-773. (b) Georgopoulos, P. G.; Roy, A.; Yonone-Lioy, M. J.; Opiekun, R. E.; Lioy, P. J. J. Toxicol. Environ. Health, B 2001, 4, 341-394.

[8] (a) Ros-Lis, J. V.; Martínez-Manêz, R.; Rurack, K. R.; Sancenón; F.; Soto, J.; Spieles, M. Inorg. Chem. 2004, 43, 5183-5185; (b) Ros-Lis, J. V.; Marcos, M. D.; Martínez-Manêz, R.; Rurack, K.; Soto, J. Angew. Chem., Int. Ed. 2005, 44, 4405-4407; (c) Basheer, M. C.; Alex, S.; Thomas, K. G.; Suresh, C. H.; Das, S. Tetrahedron 2006, 62, 605-610.

[9] (a) Cao, Q. E.; Zhao, Y. K.; Yao, X. J.; Hu, Z. D.; Xu, Q. H. Spectrochimica Acta A 2000, 56, 1319-1327. (b) International Programme on Chemical Safety. Palladium, Environmental Health Criteria Series 226, World Health Organization, Geneva, 2002. (c) Tamayo, A; Escriche, L.; Casabó, J.; Covelo, B.; Lodeiro C. Eur. J. Inorg. Chem. 2006, 2997-3004. (d) Schwarze, T.; Muller, H.; Dosche, C.; Klamroth, T.; Mickler, W.; Kelling, A.; Lohmannsroben, H. G.; Saalfrank, P.; Holdt, H. J. Angew. Chem. Int. Ed. 2007, 46, 1671-1674.

[10] (a) Batista, R. M. F.; Oliveira, E.; Costa, S. P. G.; Lodeiro, C.; Raposo, M. M. M. Tetrahedron Lett. 2008, 49, 6575-6578. (b) Raposo, M.M.M.; García-Acosta, B.; Ábalos, T.; Martínez-Manez, R.; Ros-Lis, J. V.; Soto, J. J. Org. Chem., 2010, 75, 2922-2933 and references cited.

[11] (a) Esteves, C. I. C.; Silva, A. M. F.; Raposo, M. M. M.; Costa, S. P. G. Amino Acids 2011, 40, 1065-1075 and references cited. (b) Oliveira, E.; Costa, S. P. G.; Raposo, M. M. M.; Faza, O. N.; Lodeiro, C. Inorg. Chem. Acta 2011, 366, 154-160.

[12] Yang, D.; Fokas, D.; Li, J.; Yu, L.; Baldino, C. M. Synthesis 2005, 1, 47-56.

[13] Batista, R. M. F.; Costa, S. P. G.; Belsley, M.; Raposo, M. M. M. Eur. J. Org. Chem. 2006, 17, 3938-3946.

[14] Costa, S. P. G.; Batista, R. M. F.; Raposo, M. M. M. Tetrahedron 2008, 64, 9733-9737. 
[15] Dufresne, S.; Bourgeaux, M.; Skene, W. G. J. Mater. Chem. 2007, 17, 1166-1177.

[16] (a) Seixas de Melo, J.; Burrows, H. D.; Svensson, M.; Andreson, M. R.; Monkman, A. P. J. Chem. Phys. 2003, 118, 1550-1556 and references cited therein.

[17] Lodeiro, C.; Capelo, J. L.; Mejuto J. C.; Oliveira, E.; Santos, H. M. ; Pedras, B.; Nuñez, C.; Chem. Soc. Rev. 2010, 39, 1-29.

[18] (a) Bettencourt-Dias, A.; Poloukhtine, A.; J. Phys. Chem. B. 2006, 110, 25638-25645. (b) Takagi, K.; Sugihara, K.; Isomura, T.; J. Polym. Sci. Pol. Chem. 2009, 47, 4822-4829.

[19] Valeur, Bernard; Molecular Fluorescence: Principles and Applications, Wiley-VCH Verlag GmbH, 2001.

[20] P. Gans, A. Sabatini, A. Vacca, Talanta 1996, 43, 1739-1753.

[21] Perrin, D. D.; Armarego, W.L.F. Purification of Laboratory Chemicals, $3^{\text {rd }}$ edn., Pergamon, Oxford, 1988.

[22] (a) Berlan, I. B. Handbook of Fluorescence Spectra of Aromatic Molecules, 2nd ed.; Academic Press: New York, 1971. (b) Melhuish, W. H. J. Phys Chem. 1961, 84, 229235.

\section{Captions}

Table 1. Yields, IR, ${ }^{1} \mathrm{H}$ NMR, UV-vis absorption and fluorescence data for imidazobenzocrown ethers 3-5.

${ }^{\mathrm{a}}$ For the NH stretching band (recorded in nujol).

${ }^{\mathrm{b}}$ For the NH stretching band (recorded in $\mathrm{KBr}$ ).

${ }^{\mathrm{c}}$ For the $\mathrm{N} H$ proton of the imidazole ring (in DMSO- $\mathrm{d}_{6}$ ).

${ }^{\mathrm{d}}$ in MeCN/DMSO (99:1) solution.

Table 2. Association constants for benzocrown ethers 3-5 in the presence of $\mathrm{F}^{-}, \mathrm{Pd}^{2+}$ and $\mathrm{Cu}^{2+}$ in MeCN/DMSO (99:1).

Figure 1. Absorption and emission spectra of compounds 3-5 in MeCN/DMSO (99:1), T= $298 \mathrm{~K},[3]=5.0 \times 10^{-7} \mathrm{M},[4]=5.5 \times 10^{-7} \mathrm{M},[5]=4.3 \times 10^{-7} \mathrm{M} .\left(\lambda_{\text {exc } 3}=360 \mathrm{~nm}, \lambda_{\text {exc } 4}=395\right.$ $\left.\mathrm{nm} ; \lambda_{\text {exc5 }}=415 \mathrm{~nm}\right)$. 
Figure 2. Spectrofluorimetric titration of compounds 4 (A) and 5 (B) in MeCN/DMSO (99:1) solutions as a function of added $\mathrm{CH}_{4} \mathrm{O}_{3} \mathrm{~S}$. The insets show the normalized fluorescence intensity at $500 \mathrm{~nm}$ and $535 \mathrm{~nm}$, respectively $\left([4]=4.30 \times 10^{-7} \mathrm{M}, \lambda_{\mathrm{exc}}=395 \mathrm{~nm}\right.$; [5] = $\left.5.10 \times 10^{-7} \mathrm{M}, \lambda_{\text {exc }}=415 \mathrm{~nm}\right)$.

Figure 3. Absorption and fluorescence spectra of MeCN/DMSO (99:1) solutions of 3 (A), 4 (B) and $5(\mathrm{C})$ and fluorescence titration as a function of $\mathrm{Bu}_{4} \mathrm{NF}$ added. The insets show the

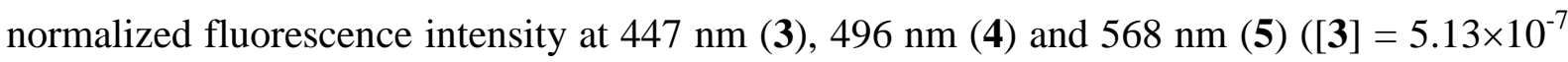
$\left.\left.\mathrm{M}, \lambda_{\mathrm{exc}}=360 \mathrm{~nm} ;[4]=4.30 \times 10^{-7} \mathrm{M}, \lambda_{\mathrm{exc}}=395 \mathrm{~nm}\right) .[5]=5.10 \times 10^{-7} \mathrm{M}, \lambda_{\mathrm{exc}}=415 \mathrm{~nm}\right)$.

Figure 4. Absorption and fluorescence spectra of MeCN/DMSO (99:1) solutions of 3 (A), 4 (B) and 5 (C) after addition of 2000 equivalents of $\mathrm{NaBF}_{4} ; \mathrm{LiBF}_{4} ; \mathrm{KBF}_{4} ; \mathrm{Ca}\left(\mathrm{CF}_{3} \mathrm{SO}_{3}\right)_{2}$ and $\mathrm{Zn}\left(\mathrm{CF}_{3} \mathrm{SO}_{3}\right)_{2}$ in $\mathrm{CH}_{3} \mathrm{CN}$. ([3] $=5.13 \times 10^{-7} \mathrm{M}, \lambda_{\text {exc }}=360 \mathrm{~nm} ;[4]=4.30 \times 10^{-7} \mathrm{M}, \lambda_{\text {exc }}=395$ $\left.\mathrm{nm} ;[5]=5.10 \times 10^{-7} \mathrm{M}, \lambda_{\mathrm{exc}}=415 \mathrm{~nm}\right)$.

Figure 5. Absorption spectra of acetonitrile-DMSO (99:1) solutions of $\mathbf{3}$ (A), 4 (B) and 5 (C) and fluorescence titration as a function of added $\mathrm{Pd}\left(\mathrm{CH}_{3} \mathrm{CN}\right)_{4} \mathrm{BF}_{4}$. The insets show the normalized fluorescence intensity at $447 \mathrm{~nm}(\mathbf{3}), 500 \mathrm{~nm}(\mathbf{4})$ and $568 \mathrm{~nm}(\mathbf{5})$. (T=298 K; [3] = $5.13 .10^{-7} \mathrm{M}, \lambda_{\text {exc }}=360 \mathrm{~nm} ;[4]=5.1010^{-7} \mathrm{M}, \lambda_{\text {exc }}=395 \mathrm{~nm} ;[5]=4.30 \cdot 10^{-7} \mathrm{M}, \lambda_{\text {exc }}=415$ $\mathrm{nm})$.

Figure 6. Absorption and fluorescence spectra of MeCN/DMSO (99:1) solutions of $\mathbf{3}$ (A), 4 (B) and 5 (C) as a function of added $\mathrm{Cu}\left(\mathrm{CF}_{3} \mathrm{SO}_{3}\right)_{2}$. The insets show the normalized fluorescence intensity at $447 \mathrm{~nm}(3), 500 \mathrm{~nm}$ (4) and $568 \mathrm{~nm}(\mathbf{5})$. ([3] $=5.13 \times 10^{-7} \mathrm{M}, \lambda_{\text {exc }}=$ $\left.360 \mathrm{~nm} ;[4]=4.30 \times 10^{-7} \mathrm{M}, \lambda_{\text {exc }}=395 \mathrm{~nm},[5]=5.10 \times 10^{-7} \mathrm{M}, \lambda_{\mathrm{exc}}=415 \mathrm{~nm}\right)$.

Figure 7. Job's plot of compound $\mathbf{3}$ in the presence of $\mathrm{Pd}^{2+}$.

Scheme 1. Synthesis of imidazo-benzocrown ether derivatives 3-5. 


\section{Research Highlights}

1- Synthesis of novel imidazo-benzo-15-crown-5 ethers bearing arylthienyl and bithienyl $\pi$ bridges.

2- Characterization of the absorption and emission properties of imidazo-benzo-15-crown-5 ethers.

3- Thienyl derivatives of benzo-15-crown-5 ethers as selective fluorescent chemosensors for $\mathrm{Pd}^{2+}$ and $\mathrm{Cu}^{2+}$.

4- bis-Substituted imidazo-crown ethers as selective fluorimetric sensors for the fluoride ion. 